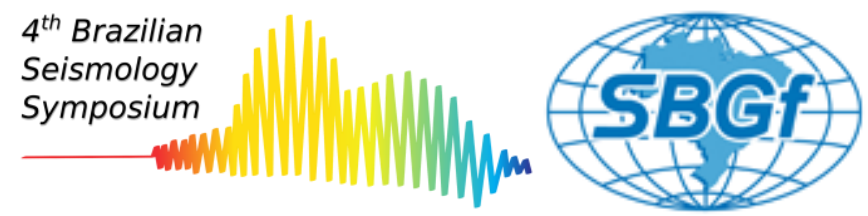

\title{
Shear wave velocity model in the Quadrilátero Ferrífero: Preliminary Results
}

Taghi Shirzad, Institute of Astronomy, Geophysics and Atmospheric Sciences, t.shirzad@iag.usp.br

Marcelo Assumpcao, Institute of Astronomy, Geophysics and Atmospheric Sciences, marcelo@iag.usp.br

Bruno Collaço, Institute of Astronomy, Geophysics and Atmospheric Sciences, bruno@iag.usp.br

Jackson Calhau, Institute of Astronomy, Geophysics and Atmospheric Sciences, jackson@iag.usp.br

Marcelo Bianchi, Institute of Astronomy, Geophysics and Atmospheric Sciences, m.bianchi@iag.usp.br

José Roberto Barbosa, Institute of Astronomy, Geophysics and Atmospheric Sciences, jose.roberto@iag.usp.br

Raphael Fernandes Prieto, VALE S.A., Raphael.Prieto@vale.com

Dionisio Carlos, VALE S.A., dionisio.carlos@vale.com

Wanderson Pereira, VALE S.A., wanderson.pereira@vale.com

\section{Abstract}

We applied a combination of the ambient seismic noise and classical source-receiver techniques to characterize the subsurface shear wave velocities in the Quadrilátero Ferrífero to a depth of about $4 \mathrm{~km}$. Ambient seismic noise data were recorded by two arrays of 16 stations deployed in the study area. To enhance the SNR of the extracted EGF signals, we divided ambient seismic records into shorter 10 min time window with $70 \%$ overlapping before correlation and stacking. To ensure retrieval EGF signals are accurate, we compared our results (obtained from ambient seismic noise) with an earthquake results occurred near to FABR station. By inspection of the $1 \mathrm{D} \mathrm{V}_{S}$ models, we inferred two main layers including upper and lower sedimentary layers. 2D mapped $V_{S}$ models indicate a low velocity anomaly around Engenho and Moeda faults.

\section{Introduction}

In regions of the sparse local earthquake records, ambient seismic noise studies is an interesting alternative to the classical methods that were used for modelling of the shear wave velocity. The ambient noise field is composed mostly seismic waves with random amplitude and phase which are sensitive to the shear waves. These waves propagate in all directions independent of a specific source so they can be used to retrieve the shear wave structure between any pair of stations.
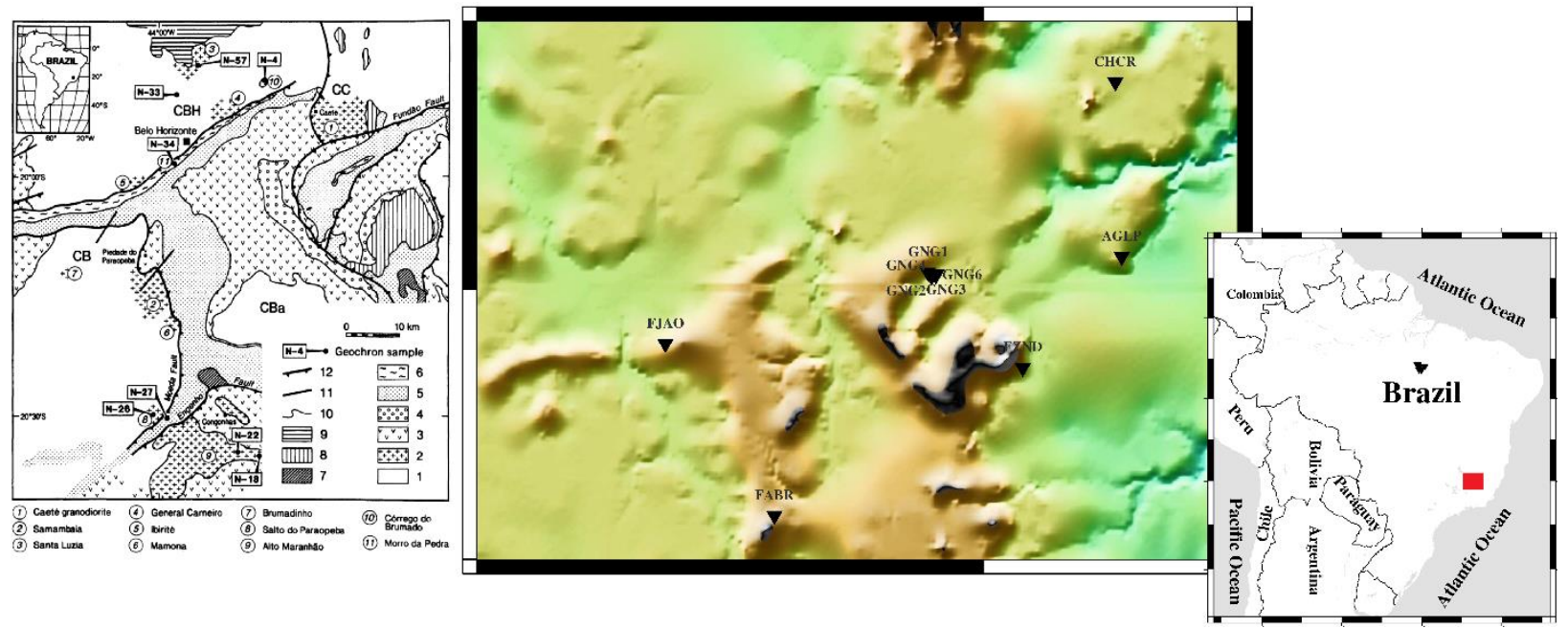

Fig.1 Map of study area. The red box in the inset map shows the study area location. Seismic stations are the inverted black triangles. Geology of the Quadrilátero Ferrífero (Noce et al., 1998) in left panel. Granitoid bodies are numbered at the figure bottom. Sample numbers are displayed inside rectangles. Legend: 1 = granite-gneiss complexes $(\mathrm{CBH}=$ Belo Horizonte complex; $\mathrm{CC}=\mathrm{Caeté} \mathrm{complex;} \mathrm{CBa}=\mathrm{Bação}$ complex; BC = Bonfim complex); 2 = Archaean and Paleoproterozoic granitoid bodies. Rio das Velhas Supergroup: $3=$ Nova Lima Group; 4 = Maquine Group. Minas Supergroup: 5 - Caraça, Itabira and lower Piracicaba groups; $6=$ Sahara Formation. $7=$ Itacolomi Group. Meso 

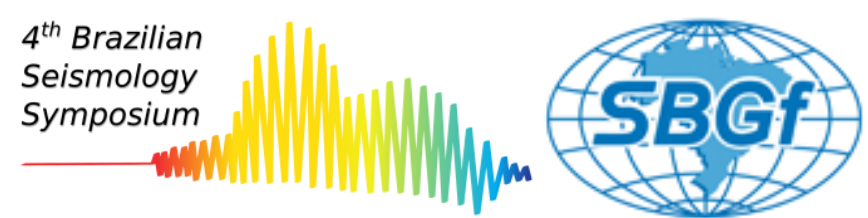

and Neoproterozoic units: 8 - Espinhaço Group; 9 = Bambui Group. $10=$ geologic contact; $11=$ vertical or undetermined faults; $12=$ thrust faults.

Ocean generated waves are the main component of the microseismic part of ambient seismic noise at periods 5-20 s, (Webb 1998). However, the shorter periods of seismic noise are dominated by higher modes of surface and body waves which are mixed with fundamental modes (Bonnefoy-Claudet et al. 2006). Numerous ambient seismic noise studies have assumed uniform distribution of noise sources or energies in different azimuths as main condition in determining the accurate empirical Green function (EGF) between the stations (e.g. Snieder 2004; Wapenaar 2004). But the uniform distribution of energies around the station-pairs only occurs in rare cases. Recent studies regarding noise source distribution (e.g., Stutzmann et al., 2009; Safarkhani and Shirzad 2019) overcome the problem via separating stationary sources, and performing stacking for these signals.

The Quadrilátero Ferrifero is located in the southern São Francisco craton in Brazil. This area, which is covered by a Neoarchean greenstone belt, is overlain by a Paleoproterozoic sedimentary succession, and surrounded by older gneiss complexes.

In this study, we present a shallow shear wave velocity model obtained from the ambient seismic noise and one earthquake occurred in the Quadrilátero Ferrifero region. The 1D shear wave profiles from all grid-points as converted to a 3D model down to $\sim 4 \mathrm{~km}$.

\section{Dataset and study area}

Continuous ambient seismic noise was recorded with two seismic networks deployed over the Quadrilátero Ferrifero. The first seismic network, shown in Fig. 1, consisted of 6 broad-band seismological stations provided by VALE. The records of this network from July 2017 to October 2020, were the main dataset in this research. The second seismic network, BL, consisted of 10 stations which are part of the Brazilian Seismic Network (RSBR). All broad-band stations are equipped with a Nanometrics Trillium Compact 120 s sensor. In addition, a $m_{R} 3.5$ micro-earthquake occurred at 23:27:26 on November $25^{\text {th }}$, 2019, was recorded by both networks. Waveforms of most stations at distances up to $100 \mathrm{~km}(\mathrm{SNR}>5)$ were also used in the inversion procedure.

A granite-greenstone belt association surrounded by granite-gneiss complexes comprise the archean terranes of the Quadrilátero Ferrífero (geological map of Fig. 1). Rio das Velhas Supergroup consists of a volcanosedimentary sequence hosting the main gold deposits of the Quadrilátero Ferrífero (Dorr etal. 1957). The greenstone belt is formed by the Tonalitic-granodioritic intrusions. At the margins of the greenstone belt, these syn-volcanic intrusions appear partially or totally in the granite-gneiss complexes surrounding the greenstone belt. Belo Horizonte (to the north of the Quadrilátero Ferrífero), Caeté (to the northeast), Bação (in the center), and Bonfim (to the west) are complex units of the granite-gneiss terranes (Herz 1970). The Archaean units overlie tectonically by the Proterozoic Minas Supergroup, hence the Caraça (predominantly quartzites and phyllites), Itabira (mainly Lake Superior-type banded iron formation, and dolomitic carbonates with stromatolites), and Piracicaba groups are comprised (Dorr 1969; see geological map of Fig. 1). Moreover, the main feature of the Piracicaba Group is the interbedded quartzite and phyllite containing carbonic lenses. Also, Its upper unit (Sabará Formation) covers by phylites, chlorite schists, conglomerates, quartzites, graywackes, and rare iron formation (Machado et al., 1992).

\section{Methodology}

\section{1 pre-processing preparations}

We first divided the continuous raw data into 10 min time windows (see Seat et al. 2012; Shirzad and Shomali 2013) to enhance the final inter-station EGF signal. The standard ambient seismic noise low frequency approach was then used as described by Bensen et al. (2007). Time (one-bit) and frequency (whitening) domain normalizations were performed. This step nullifies and suppresses the influence of instrument irregularities, human activities, and earthquake signals. According to studies of Pedersen et al. (2007), a 5-point zero-phase bandpass Butterworth pre-filtering was applied in the period range of 0.5 to $5.0 \mathrm{~s}$. The prepared signals are finally cross-correlated for all available stations pairs with $70 \%$ overlapping of time window. For each station pair, 

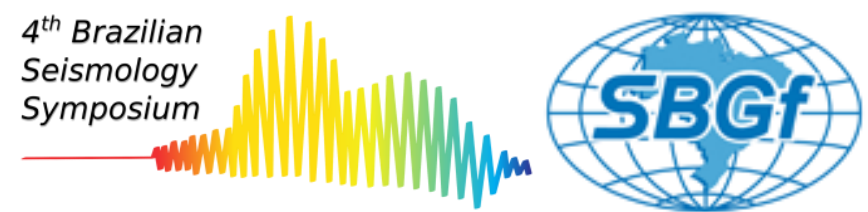

the 10 min cross-correlation functions are stacked using WRMS stacking method outlined by Shirzad and Assumpcao (2019). Fig. 2 indicate a section of extracted EGF signal as a function of inter-station of distance.
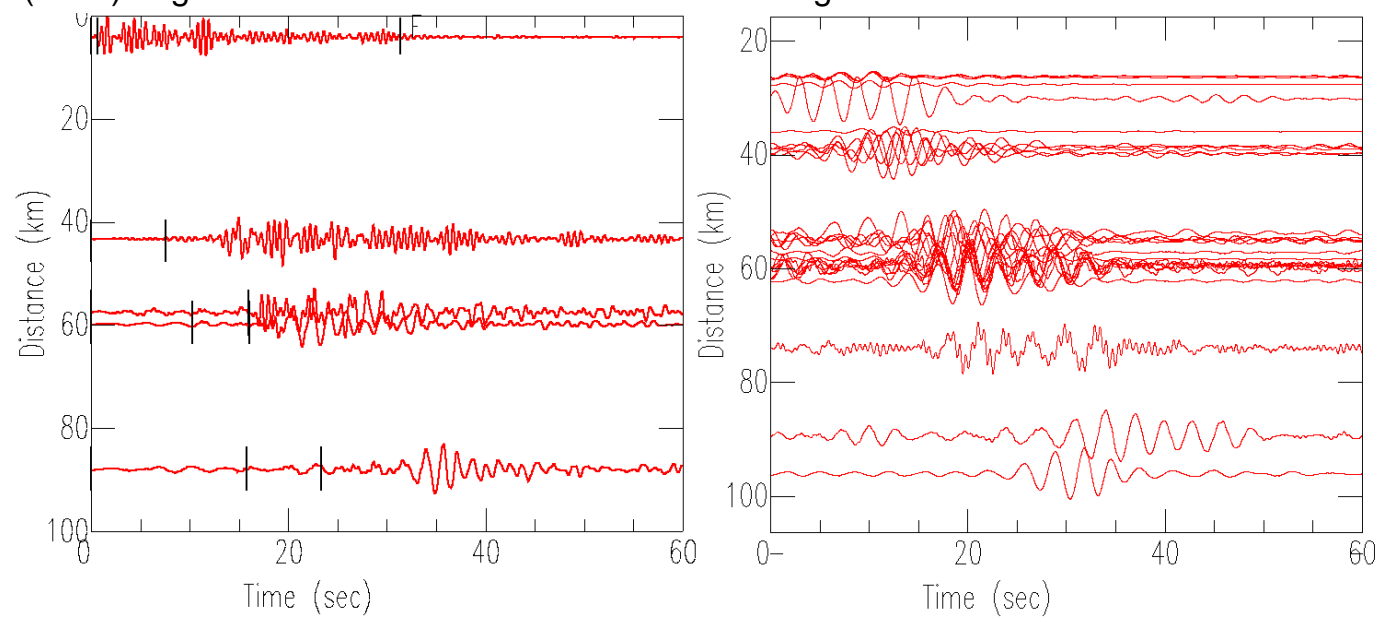

Fig. 2 Signal section for recorded waveforms of earthquake (left) and inter-station EGF (right) in the period range of 0.5 - 5.0 s.

\subsection{Dispersion curves}

To calculate Rayleigh wave group velocity dispersion curves, the multiple filter analysis (Dziewonski, et al., 1969) with the phase-matched filter technique (Herrin and Goforth 1977) was used. Applying such filters causes resolution uncertainties in the time-frequency domains (Heisenberg's uncertainty), so that larger values of the Gaussian filter width $(\alpha)$ increase the resolution in the frequency domain while the resolution is limited in the time domain (Mallat, 2004). Hence, a suitable Gaussian filter width, $\alpha$, was set based on the inter-event distances. Because of the epicentral distance of micro-earthquake to FABR is less than $2 \mathrm{~km}$, this station is used as a reference in this research for comparing results. Fig. 3 represents the Frequency-Time Analysis (FTAN) of micro-earthquake on the station of GNG6 (left panel) and FABR-GNG6 (middle panel). We used the computer program from the seismology package of Herrmann and Ammon (2002) for both earthquake waveforms and inter-station EGF signals to calculate Rayleigh wave group velocity dispersion curves within the expected wave signal window ( 2.0 to $4.2 \mathrm{~km} / \mathrm{s})$, and $\alpha$-values of 3 and 6 were appropriate for inter-event distances shorter and larger than $50 \mathrm{~km}$, respectively.
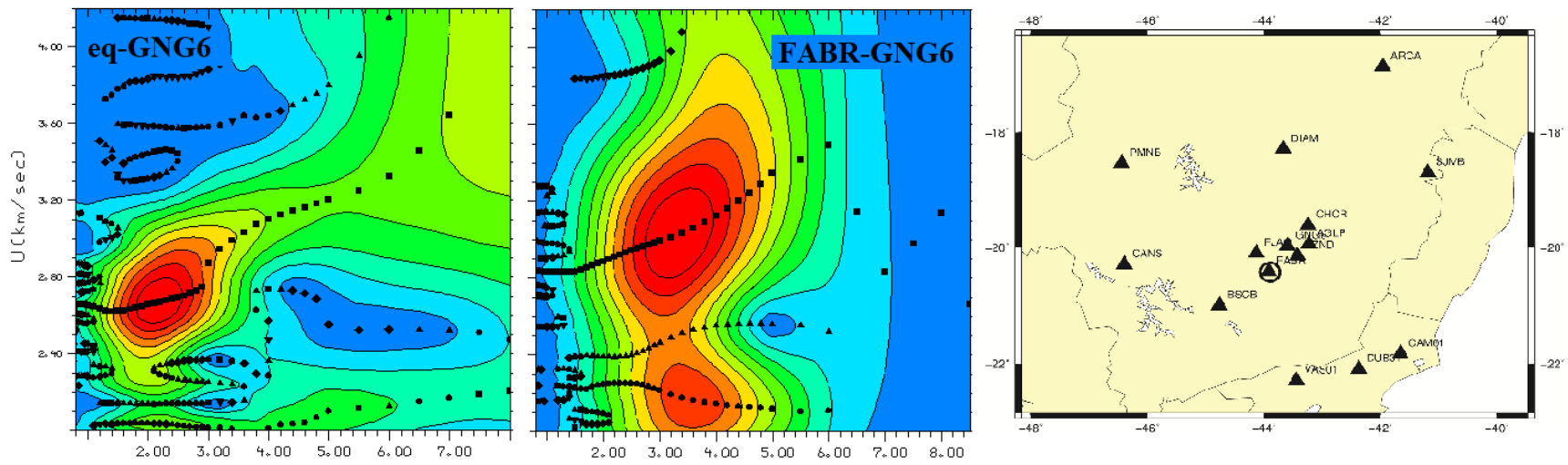

Fig. 3 Frequency-Time Analysis (FTAN) for earthquake recorded on GNG6 and inter-station FABR-GNG6. The earthquake location is depicted by the open circle. The closest station is FABR.

\subsection{Depth inversion}

The group velocity Rayleigh wave dispersion curves can be inverted at depth to obtain $1 \mathrm{D} \mathrm{V}_{\mathrm{s}}$ profiles. For this inversion procedure, an iterative damped least-squares inversion procedure was applied using surf96 computer program (Herrmann and Ammon 2002). The initial $V_{S}$ model with multiple layers of constant thickness $(500 \mathrm{~m})$ 

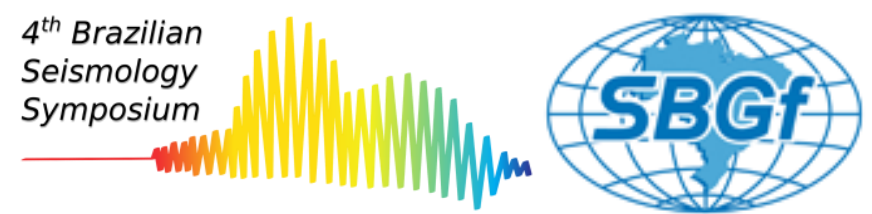

was parameterized into a half space from the surface to a depth of $8 \mathrm{~km}$ without any low velocity layer (channel). Fig. 4 shows two example of the depth 1D inversion results for calculated dispersion curves of the microearthquake on the station of GNG6 and FABR-GNG6.
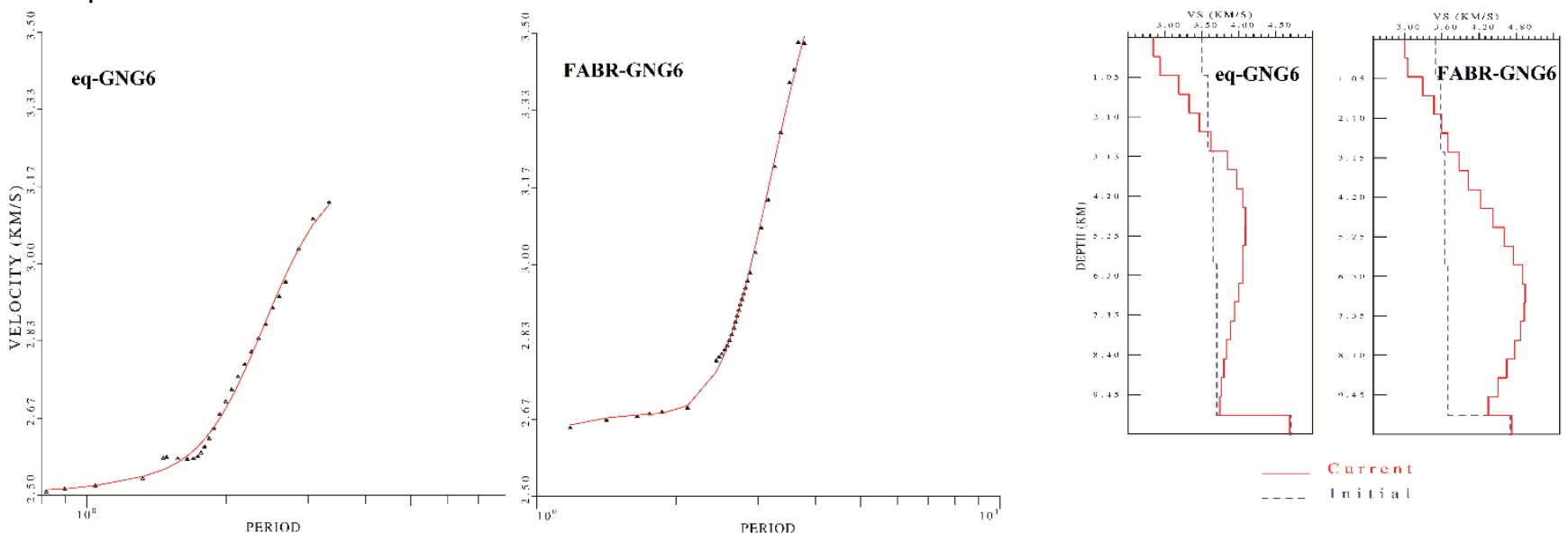

Fig. 4 The left panel indicate the dispersion curves for earthquake waveform recorded on GNG6 and inter-station FABR-GNG6. The right panel show the 1D initial (dotted blue) and calculated (solid red) models for eq-GNG6 and FABR-GNG6. The synthetic dispersion curves (red line) were generated by calculated $1 \mathrm{D} \mathrm{V}_{\mathrm{S}}$ model.

\section{Discussion}

In ambient seismic noise studies, the period range and the spatial coverage are controlled by the inter-station distances, their azimuthal orientations, and the number of coincident recorded days. This period range of extracted EGF signals reveals the depth range and also depth resolution of shear wave velocity models. By applying common low frequency single station pre-processing steps, cross-correlating and then using stacking procedure, the inter-station EGFs were extracted in the Quadrilátero Ferrífero region. A reasonable similarity was observed between the dispersion curves and also 1D $V_{S}$ models of the earthquake and inter-station EGF (e.g., Eq-GNG6 and FABR-GNG6; see Figs. 3 and 4).

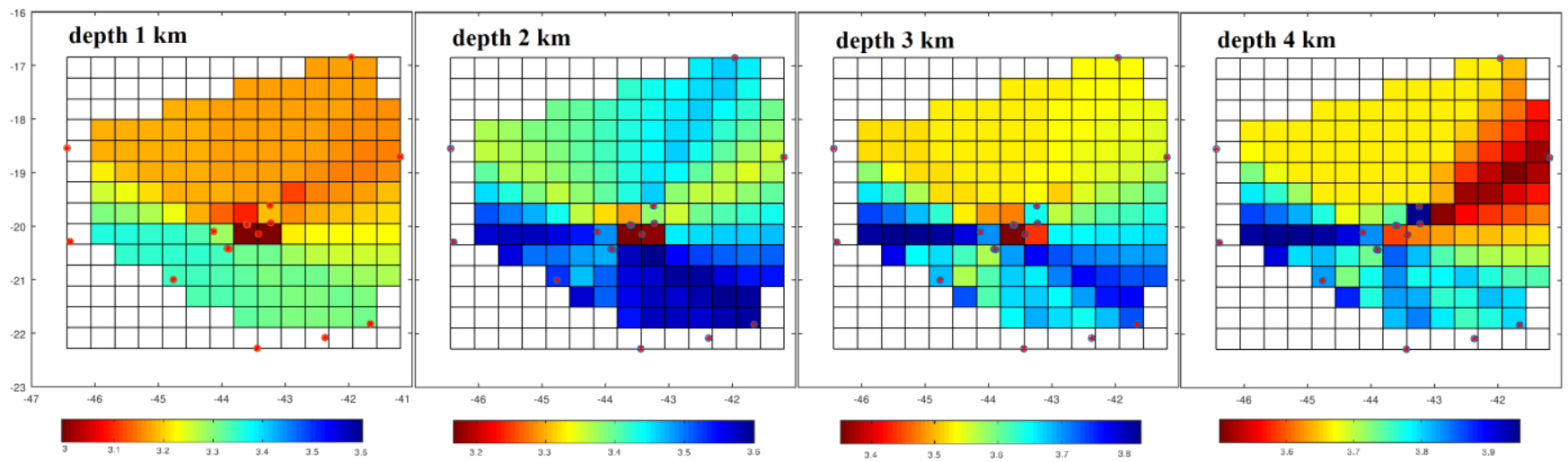

Fig. 5 The 2D shear wave velocity mapped on depths 1, 2, 3, and $4 \mathrm{~km}$. The seismic stations show by circles. The VS model calculated from Rayleigh wave group velocity.

The depth inversion of surface waves can resolve sufficiently the velocity anomalies, although the depth and the topography of different horizons are less well constrained, due to the 1D inversion scheme. The 1D $V_{s}$ models generally picture out two main layers including upper and lower layers. The upper surface layer thickness varies between 1-2 km. After calculating all $1 \mathrm{D} \mathrm{V}_{\mathrm{s}}$ models, the 2D $\mathrm{V}_{\mathrm{s}}$ model can be prepared as horizontal maps as shown in Fig. 5. According to this figure, low velocity anomaly appears in the region of the Engenho and Moeda faults. Moreover the Bambui Group in the south has a higher velocity than the Nova Lima Group in the north. 


\section{Conclusion}

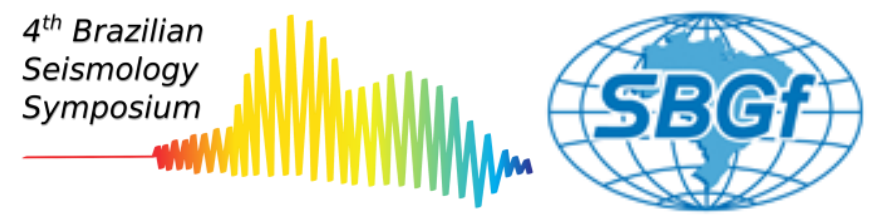

This study attempts to define the first shear wave velocity model of the shallow layers of the Quadrilatero Ferrífero as preliminary results. Though the common low frequency data preparations of the ambient seismic noise were used, the stacking procedure was applied based on the homogenization of energy flux in the study area. Our result indicates a similar dispersion between earthquake and inter-station EGF, and 1D $\mathrm{V}_{S}$ models. The 2D $V_{S}$ maps show lower velocities anomaly around the Engenho and Moeda faults.

\section{References}

Bensen, G.D., Ritzwoller, M.H., Barmin, M.P., Levshin, A.L., Lin, F., Moschetti, M.P., Shapiro, N.M., Yang, Y., 2007. Processing seismic ambient noise data to obtain reliable broad-band surface wave dispersion measurements. Geophys. J. Int. 169, 1239-1260.

Bonnefoy-Claudet, S., Cotton, F., Bard, P.-Y., 2006. The nature of noise wavefield and its applications for site effects studies: a literature review, Earth Sci. Rev., 79(3), 205-227.

Dorr II, J.V.N.; Gair, J.E.; Pomerene, J.G.; Rynearson, G.A. 1957. Revisão da estratigrafia pré-cambriana do Quadrilátero Ferrífero. Rio de Janeiro, DNPM-DFPM, 31 p. (Avulso 81).

Dziewonski, A., Bloch, S., Landisman, M., 1969. A technique for the analysis of transient seismic signals, Bull. Seismol. Soc. Am. 59, 427-444.

Herrin, E.E., Goforth, T.T., 1977. Phase-matched filters: Application to the study of Rayleigh Waves, Bull. seism. Soc. Am., 67, 1259-1275.

Herrmann, R. B., Ammon, C. J., 2002. Computer programs in seismology-surface waves, receiver functions and crustal structure. Saint Louis University http://www.eas.slu.edu/People/RBHerrmann/ComputerPrograms.html

Herz, N. 1970. Gneissic and igneous rocks of the Quadrilátero Ferrífero, Minas Gerais, Brazil. U.S. Geological Survey Professional Paper, 641-8:1-58

Machado, N.; Noce, C.M.; Ladeira, E.A.; Belo de Oliveira, O.A. 1992. U-Pb geochronology of Archean magmatism and Proterozoic metamorphism in the Quadrilátero Ferrífero, southern São Francisco Craton, Brazil. Geological Society of America Bulletin, 104:1221 -1227

Mallat, S., 2009. A Wavelet Tour of Signal Processing, Academic Press,14-20.

Noce, C. M., Machado N., Teixeira W., 1998, U-Pb geochronology of gneisses and granitoids in the Quadrilátero Ferrífero (Southern São Francisco Craton): age constraints for Archean and Paleoproterozoic magmatism and metamorphism, Revista Brasileira de Geociências, 28, 95-102.

Pedersen, H. A., F. Krüger, and the SVEKALAPKO Seismic Tomography Working Group, 2007. Influence of the seismic noise characteristics on noise correlations in the Baltic shield, Geophys. J. Int. 168, 197-210.

Safarkhani, M., Shirzad, T., 2019. Improving C1 and C3 Empirical Green's Functions from ambient seismic noise in NW Iran using RMS-ratio stacking method, Journal of Seismology, $23,787-799$.

Seats J.K., Lawrence J.F., Prieto, A.G., 2012. Improved ambient noise correlation functions using Welch's method. Geophys. J. Int., 188:513-523.

Shirzad, T., Assumpcão, M., 2019. Extracting optimum interstation empirical Green's function in west-central Brazil, in 3rd Brazilian Seismology Symposium, Vinhedo, Sao Paulo, Brazil.

Shirzad, T., Shomali, Z.H., 2013. Shallow crustal structures of the Tehran basin in Iran resolved by ambient noise tomography. Geophys. J. Int. 196, 1162-1176. http://dx.doi.org/10.1093/gji/ggt449.

Snieder, R., 2004. Extracting the Green's function from the correlation of coda waves: a derivation based on stationary phase. Phys Rev E 69, 046610. https://doi.org/10.1103/PhysRevE.69.046610.

Stutzmann, E., Schimmel, M., Patau, G., Maggi, A., 2009. Global climate imprint on seismic noise, Geochem. Geophys. Geosyst., doi:10.1029/2009GC002619.

Wapenaar, K., 2004. Retrieving the elastodynamic Green's function of an arbitrary inhomogeneous medium by cross correlation. Phys Rev Lett 93, 254301. https://doi.org/10.1103 /PhysRevLett.93.254301 


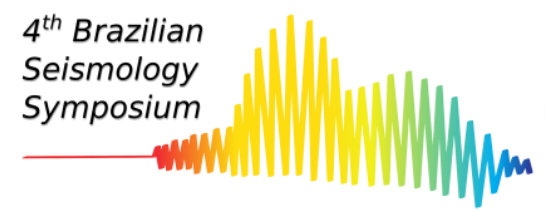

Webb, S., 1998. Broadband seismology and noise under the ocean, Rev. Geophys., 36, 105-142.

\section{Awknoledgement}

This study used the data provided by the VALE QF network and the Brazilian Seismic Network (RSBR). This work was also supported by the Fundação de Amparo à Pesquisa do Estado de São Paulo (FAPESP), São Paulo, Brazil [project 2013/24215-6 and grant 2016/20952-4]. We thank Wanderson Tenório (VALE) for field maintenance of the QF seismic network. 